\title{
The role of the State in fostering innovation activity: case studies of the USA and Germany
}

\author{
O papel do Estado na promoção da atividade de inovação: \\ estudos de caso dos EUA e da Alemanha
}

JOSÉ LUIS GORDON*

\begin{abstract}
RESUMO: O artigo procura analisar o papel do Estado no estímulo à atividade de inovação nos EUA e na Alemanha. Argumenta-se que os governos nesses países exercem papel ativo na inovação, porém cada qual atua com diferentes objetivos e instrumentos para estimular e induzir atividade de inovação nas empresas. São analisados alguns casos específicos de políticas de fomento à inovação em cada país a fim de demonstrar a atuação do poder público em contextos distintos. Conclui-se que a política de inovação é flexível e adaptável a cada contexto, porém o papel ativo do Estado se destaca em ambos os países.

PALAVRAS-CHAVE: Inovação; Estado; política pública.
\end{abstract}

ABSTRACT: The present study analyzed the role of the State in fostering innovation in the USA and Germany. It was argued that governments in these countries play an active role in innovation, but each one operates with dissimilar objectives and tools, to stimulate and induce innovation activity in companies. Some specific cases of innovation policies in each country were analyzed to demonstrate the performance of the public power in different contexts. It was concluded that innovation policy is flexible and adaptable to each context, but the active role of the State stands out in both countries.

KEYWORDS: Innovation; State; public policy.

JEL Classification: O31; O25; O38.

\section{INTRODUCTION}

The role of the State in leading and fostering innovation activity in countries is often an issue during debates on innovation policies. The issue discoursed in the present study is: to what measure the State, when employing its different tools, can

\footnotetext{
* Diretor de Planejamento e Gestão da EMBRAPII - Empresa Brasileira de Pesquisa e Inovação Industrial, Brasília/DF, Brasil. E-mail: jlplgordon@gmail.com. Orcid: https://orcid.org/0000-0002-13481558. Submitted: 27/December/2017; Approved: 12/February/2019.
} 
be considered an essential actor arousing the innovative process in countries? Moreover, how can the State be capable to shape the national innovation system (NIS) to create a dynamic of generation and diffusion of endogenous new knowledge? The present study addresses these questions as from case studies of some of the most innovative countries - The United States of America (USA) and Germany.

The concept "national innovation system" - or NIS - is used as a starting point to address the above-mentioned queries (Cassiolato; Lastres, 2005). Some key aspects of NIS are highlighted, so that the need for an innovation policy is understood: firstly, the main locus of the innovation dynamics is the company, essentially the private one; in some cases, the state-owned company, which can play a role in inducing innovations along its chains (Gadelha, 2001). Relevantly, the current literature suggests that the environment in which the company is inserted plays an important role to condition its innovation strategy. There are issues connected to macroeconomic variables, such as interest and exchange rates, barriers to entry, regulations, among others, that may condition the innovative activities of the companies (Cassiolato; Lastres, 2005; Gadelha, 2001).

Lastly, NIS's analytical framework allows to recognize and analyze the role of the State within the innovative dynamics by giving means and inducing companies to innovate according to their capacity to influence economic activities in general (Mazzucato, 2013; Cassiolato, 2016; Atkinson; Ezell, 2012). In this sense, throughout public policies, the State can exert relevant role in the dynamics of generation and diffusion of knowledge, and the visible hand (Block, 2011) of the public sector becomes present.

The successful experiences of economic development presented as one of its main components a strong national State, able to articulate interests around the development of the country, with great participation of the business sector (Bresser-Pereira, 2017; Gadelha, 2016; Mazzucato, 2013; Atkinson; Ezell, 2012; Gadelha, 2001). In this context, it would be up to the State to create policies to guide both innovative and industrial activities, to contribute to strengthen the incorporation and the diffusion of knowledge in the national productive sector. There is abundant literature showing that developed countries, historically, have had an inductive State which thrives the innovative process (Reinert, 1999; Mazzucato, 2013; Block, 2011; Atkinson; Ezell, 2012; Cassiolato; Lastres, 2005).

The hypothesis investigated was that the State's visible hand foments conditions to generate innovation-led growth, promoting interaction between the public and the private sectors (Mazzucato, 2013; Block, 2008). The State may operate influencing the process of learning and generating new knowledge, since it provides a series of tools that contribute with economic and social development of the nations (Mazzucato, 2013; Block, 2008; Atkinson; Ezell, 2012). Hence, the dichotomous opposition between the State and the market is false, in view of the clear existent interaction in the innovative process between both agents.

Interactions and interdependencies between private and public sectors are of 
that creating a productive system that values nontangible knowledge, interactive learning, and investment increase upon innovation. In this context, the role of the public power may vary, using different tools for supply and demand (Rothwell, 1983) to promote the innovative activity in companies, and to generate a favorable environment for innovation. Public policies may promote and induce new knowledge incorporation and, in a few situations, contribute to the companies to leave technological lock-in, and generate new markets. The government can contribute to change the position of agents in this situation, because what may be happening is that both companies and research institutions are in a condition of a technological lock-in (Freeman; Soete, 2008).

To demonstrate how the State in fact materializes its support to the innovation activity, it was assayed the case of two countries amongst the main worldwide economies: United States of America, and Germany (FMI, 2015). These two countries are also amongst the main innovative countries, according to Insead's Global Index 2015 (Insead, 2016). Therefore, the present study analyzed, using NIS's referential (Cassiolato; Lastres, 2005), how can the State shape the innovative process in these two countries. It was highlighted how these nations' public sector has operated to induce and foment innovative actions and, therefore, demonstrate which has been the State's role. To understand how developed economies have articulated the different policies tools is a way to understand how the innovative agenda has been stimulated. Therefore, some specific cases of public politics were assayed to understand how the government had structured itself to support research and development activities (R\&D).

This study was structured according to: Introduction; a second chapter analyzed the USA's case, to understand the under-discussion process; a third chapter assayed Germany's case; lastly, Conclusion.

\section{THE INDUCING STATE IN THE USA}

Some authors that analyze the US economy point out that, in innovation policy actions and in other areas of the economy, there is a government induction and stimulation and a large amount of federal resources applied to induce technological development through different tools in the country (Mazzucato, 2013; Atkinson; Ezell, 2012; Mowery, 2010). The amount of federal resources in R\&D in the year of 2017 reached US\$ 144 billion. Provenance of resources to stimulate the endogenous generation of new knowledge in the USA, according to different areas, is ascertained in Figure 1.

There has been great predominance of expenses in the defense sector, averaging $56.0 \%$ of total federal public expenses in R\&D, from 1999 to 2017, which infers the relevance of the area in the induction and foment of innovation endeavors. The large amount spent by the defense department in innovation activities is a charac- 
Figure 1: Percentage of the Federal Budget in US R\&D,

by National Targets (US\$ Constants, 2016)

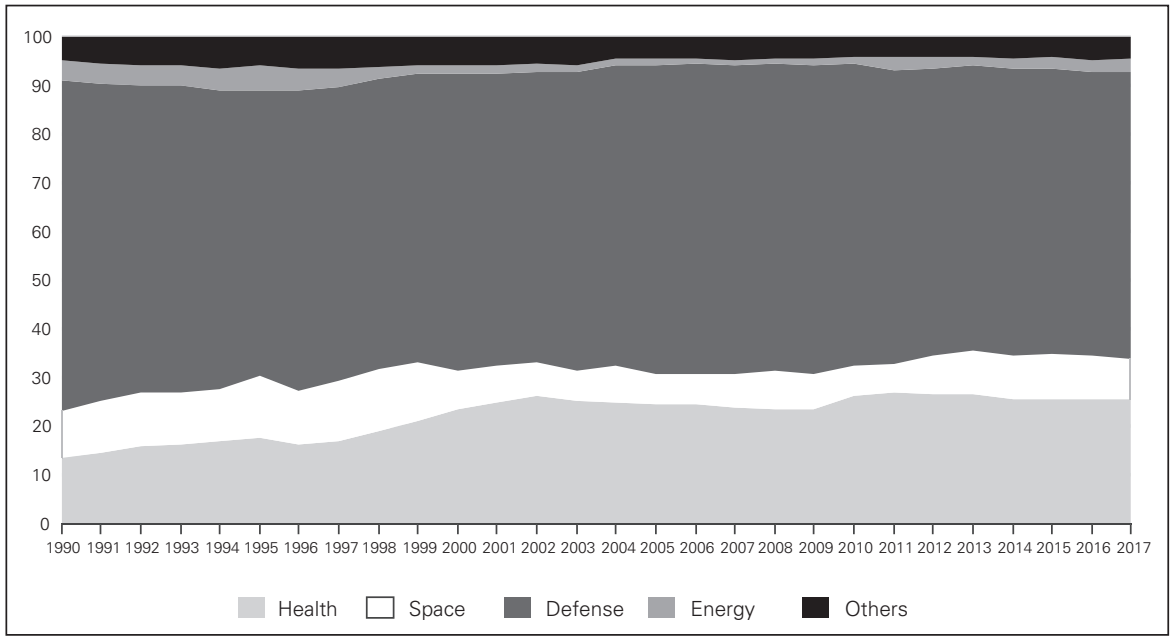

Source: AAAS, based on OMB Historical Tables in Budget of the United States Government FY 2017. Constant dollar conversions based on GDP deflators.

teristic of the United States' NIS. The health sector represents $22.0 \%$ on average of the total applied resources; the space area resources are $7.0 \%$ on average; ${ }^{1}$ and the energy sector, which started to expand again from 2009 , is up to $2.0 \%$. This demonstrates the concentration of expenses in the North American strategical fields, and mirrors the priorities where sums are allocated.

Another characteristic is that resources arising from the public sector are more directed to applied research and development - Figure 2. That, in a way, evidences focus and strategy fostering actions with greater chances to improve the innovative capacity of the country's companies ${ }^{2}$ and the public demands (Mowery, 1992; Block, 2008).

To better understand how the US State operates placing its resources and using its different tools of supply and demand to enhance the country's innovative capacity, some case studies will be highlighted. Firstly, the Defense Advanced Research Projects Agency (Darpa), which is the Department of Defense (DOD) main agency for the promotion of technological development. Next, the Small Business Innovation Research (SBIR), a

\footnotetext{
1 "The United States is an outlier, with large R\&D programs in defense and health bringing the total 'mission-oriented' R\&D budget to well over $90 \%$ of federal-government R\&D spending” (Mowery, 2010, p. 1222).

2 "For most of the past half-century, industry has performed $60-70 \%$ of DoD-funded R\&D (this definition of 'defense-related R\&D' excludes some R\&D related to nuclear weapons, funded by the Atomic Energy Commission (AEC) and successor agencies, including the Department of Energy), government laboratories (excluding contractor-operated laboratories) have performed 20-30\%, and US universities (including their 'federally funded R\&D centers' - FFRDCs) have performed 3-5\%" (Mowery, 2010, p. 1229).
} 


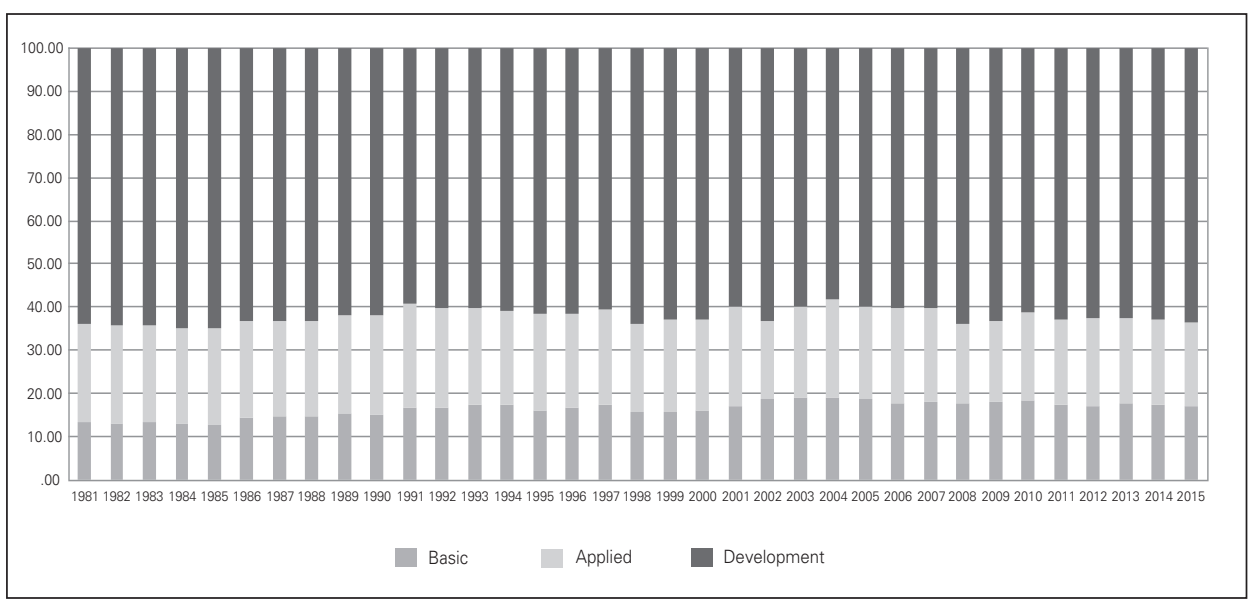

Source: NSF.

model that connects public subsidy to small business projects with government procurement and that is considered one of the most successful models in boosting innovations (Mazzucato, 2013; Block, 2008; Connell, 2014).

\section{Defense Advanced Research Projects Agency - Darpa}

DOD is the leading creator of demand and funding for technology projects in the US (Gordon, 2017). One of the main agencies for innovation stimulus linked to DOD is Darpa, established in 1948, in response to the Soviet Union's Sputinik project.

Initially, Darpa should pursue what was called blue sky thinking, i.e., frontier technologies that would be used few years ahead. The Darpa's main differential compared to existing institutions for fostering innovation activities is that it is less bureaucratic, ${ }^{3}$ which allows us to fulfill goals more assertively, often establishing goals and orienting researches, using a mission-oriented model (Block, 2008; Connell, 2014).

One of the outstanding projects in the initial years of the model was the funding of computer research in the 1960s and 1970s. During this process, Darpa's Information Processing Techniques Office (IPTO) laboratory was instrumental in the development of technologies which are now incorporated into personal computers, for instance, semi-conductors and the internet. In large measure, these are technologies that can be considered "radical", or that have great technological impact.

Darpa's operating model follows:

\footnotetext{
${ }^{3}$ Darpa is an institution free from the rules to acquiring weapons, which bind bureaucracies and restrictions (Connell, 2014).
} 
- A series of relatively small offices, often staffed with leading scientists and engineers, are given considerable budget autonomy to support promising ideas.

- These offices are proactive rather than reactive and work to set an agenda for researchers in the field. The goal is to create a scientific community with a presence in universities, the public sector, and corporations that focuses on specific technological challenges that have to be overcome.

- Funding is provided to a mix of university-based researchers, start-up firms, established firms, and industry consortia. There is no dividing line between "basic research" and "applied research," since the two are deeply inter-twined. Moreover, Arpa personnel are encouraged to cut off funding to groups that were not making progress and reallocate resources to other groups that had more promise.

- Since the goal is to produce usable technological advances, the agency's mandate extends to helping firms get products to the stage of commercial viability. This can involve the agency in providing firms with assistance that goes well beyond research funding.

- Part of the agency's task is to use its oversight role to make constructive link ages of ideas, resources, and people across the different research and development sites (Block, 2008, p. 7).

The main idea is to support innovations that may be used in practice by companies and by the defense sector. To a large extent, these are technologies of frontier knowledge. The agency seeks to develop a range of links with universities and federal laboratories in order to coordinate a network capable of generating technological developments from the demands of the area of defense. Much of this development has a stimulus to be implemented in partnership with the productive sector. Herewith, it is possible to characterize the existence of intervention of the public sector in the determination of the technological trajectories to strengthen US's innovative capacity.

Darpa's managed resources are based on the institution's strategy, and there is a concern with the use of innovation, and not simply with research that does not have applicability. The projects have goals and purposes that are followed by the team to evaluate their development. Therefore, the cost and risk reduction (non-reimbursable resources ${ }^{4}$ for resources for scientific and technological institu-

\footnotetext{
${ }^{4}$ In this study it was considered non-reimbursable resources those that can be utilized to foster R\&D projects and do not need to be refunded to the foment institution. In this paper we will divide nonreimbursable resources into two main categories: non- reimbursable for STI and enterprise interaction and grant. The concept of can be used to design research institutions or projects involving research institutions and companies. The term non-reimbursable resources for STI and enterprise interaction will be used for projects between the two agents, but the resources are allocated in the STI, even for projects of the companies. When applying the term non-refundable will be referring both possibilities. This
} 
tions - STI - and enterprise interaction, grant and technological orders) are used in coordinated means with DOD's strategical needs. In addition, the defense demands allow greater induction of technologies that are, in their majority, at the frontier of knowledge.

Darpa does not develop projects directly, yet, through its tools, mainly nonreimbursable resources for STI and enterprise interaction, grant and public procurement, ${ }^{5}$ often from technological orders for military purposes (Squeff; De Negri, 2017). Therefore, operates according to the demands of its "clients": Armed Forces, Army, Navy and the Department of Defense. ${ }^{6}$ DOD is amongst the top technology purchasers in the US (Gordon, 2017). With this model, the agency influences from small ${ }^{7}$ to large companies, besides research lead in universities and research laboratories (Mowery, 2010). With an annual budget of US\$ 3 billion/year (Gordon, 2017), the institution subsidizes projects, most of them are grant.

differentiation is applied in Brazil; in other countries such distinction does not exist. The concept in countries such as Germany and USA is grant that may be destined to companies, STI etc.

${ }^{5}$ According to Vonortas et al. (2010), most purchases are made by federal agencies, e.g., the DOD and DOE. The US model presents the specificity of having a special status for certain public purchases that generate greater easiness of the operation of the system. The fact that there are confidential purchases can allow the system to carry out deliberate actions to stimulate technologies and local production. Bidding models may involve competition or have a sole provider (negotiation). The competition model involves several bids. For instance, in the military this competition model is inadequate, thus, negotiation is utilized. Therefore, the model of negotiation differs from bidding where negotiation may imply some bargain and because it does not necessarily involve prize for the lowest price (Robinson, 2008). In the negotiation model, the government compromises to pay for all contract expenses, plus a fixed rate. According to Robinson (2008), most purchases for the Iraq War adopted the negotiation model. Thus, there is much independence for the purchases for the military, which allows much discretion in government purchases. The existence of the negotiation model allows the government to comply with the country's economical and social interests more directly. Therefore, the military case is emblematic, because in addition to the issue of secrecy, it may operate off competition limits, which eases the development of technologies.

${ }^{6}$ In the case of Darpa, it is said that R\&D acquisition processes are relatively dissimilar from those of civil agencies (Rauen, 2017). In such institutions the project manager - PM (Squeff; De Negri, 2017) plays an essential role in the definition of the institutions' agenda. Secondly (Squeff; De Negri, 2017), two main means by which PMs identify projects can be defined. First, the identification of the emergence of the scientific field, and second, the identification of the needs of its end users (area of defense). PMs play a main role in the process of defining, monitoring projects ran by Darpa. They will be in constant touch with the academic units, with the demands of the defense sector and all its network to be able to define projects. The contracting officers get in touch with companies, once projects' schedules are defined, to discuss the capabilities of productive structures to comply with its needs (Rauen, 2017). Thence, most projects in that field use the negotiation process instead of traditional bidding, as previously discoursed.

7 "The much-cited innovative cluster of Silicon Valley is the most visible expression of strong innovation dynamics that can emerge from the evolution of linkages among dominant innovative firms (e.g. Fairchild), government funding agencies (e.g., Darpa), the geographical interaction of young firms, an outward-oriented university system, new forms of intermediaries like venture capitalists and 'angels', and the formation of strategic partnerships between firms manifested in alliances, patent licensing, and patent pools. Tracking and understanding these dynamics are important for forging policy that supports this experimentation while retaining a competitive environment" (Colecchia, 2006, p. 6). 
Figure 3 demonstrates some of the characteristics of Darpa's support to R\&D projects. The institution invests great amount of its resources on applied research and on the Advanced Technology Development program (ATD), aimed at the concept and testing phase, to overhaul the capability of research to be used for military purposes. These two together portray, on average, more than $80 \%$ of the total amount of resources' use that have a more applied end to the use of technologies. Therefore, resources are allocated aiming to become staggered technologies to be implemented in both the productive and the defense sectors (Mowery, 2010). This does not mean that projects are less at the frontier of knowledge, but rather focused on use of military area, in principle. Subsequently, many end up gaining civilian use, e.g., internet, personal computers, semiconductors, amongst others (Mowery, 2010; Block, 2008; Connell, 2014). From its technological orders, Darpa supports several projects with same technological purpose of seeking different solutions for its clients demands. Nonetheless, because these are risky projects, they are prone to failure and that is acceptable, given the nature of the projects (Squeff; De Negri, 2017). Often, this set of projects leads to the development of other technologies which end up being absorbed by the plaintiffs and the civilian society. Therefore, the concern is less in project to project, but in a portfolio of risk projects that have an objective centered on the demands of the State.

Figure 3: Darpa's Resources Percentage by Function

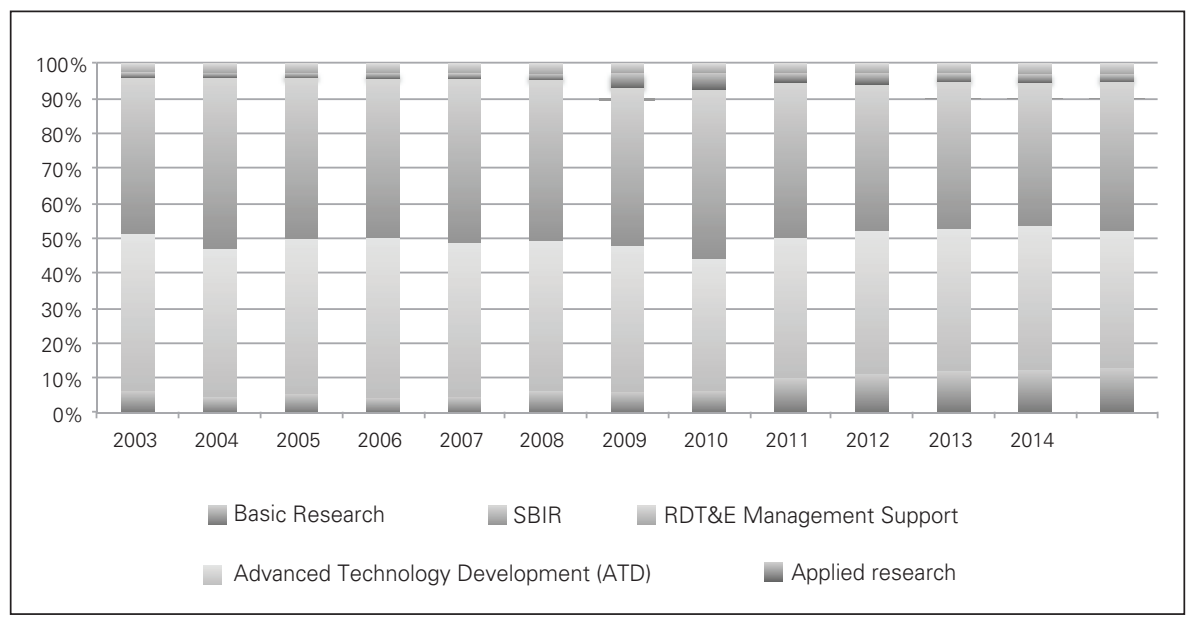

Source: DARPA.

In the light of the foregoing, Darpa is empowered to mold or create markets using its variety of tools, e.g., public procurement, public technological orders, and funding capacity (grant). In a way, the institution can "pick the winners", not an individual company, but those out of a process of competition in winning areas and technologies. Also, this process is highly connected to a State-run strategical agenda, in a mission-agency oriented model (Mowery, 2010). 


\section{Small Business Innovation Research (SBIR)}

The Small Business Innovation Research (SBIR) was established in 1982 to arouse small US companies to engage in R\&D with commercial potential.

The program works as follows: each year, federal agencies with external research and development activities, whose budgets exceed US\$100 million, must allocate a percentage (Table 1) of their R\&D budget to the program. Each agency administers the program independently, according to Congress's established baselines. Currently, there are 12 agencies that apply to this program.

Table 1: Annual percentage that institutions must invest on SBIR

\begin{tabular}{|c|c|c|c|c|c|c|}
\hline 2011 & 2012 & 2013 & 2014 & 2015 & 2016 & 2017 \\
\hline $2.5 \%$ & $2.6 \%$ & $2.7 \%$ & $2.8 \%$ & $2.9 \%$ & $3.0 \%$ & $3.2 \%$ \\
\hline
\end{tabular}

Source: SBIR.

The key-elements of the program are the following:

- Agencies advertise topics (solicitations) in groups, typically twice a year; each topic relates to an agency's requirements for new technology, either for its own use or to meet its broader objectives. Only majority US owned forprofit businesses are eligible and the R\&D must be undertaken in the US (Connell, 2014, p. 31).

- It is a competitive process opened to all businesses that employ 500 people or less, and that are mostly North American citizens owned.

The program is divided into three phases.

On Phase I, the goal is to establish the technical merit, viability, and commercial potential of R\&D effort proposals and determine the quality performance of the small award-winning enterprises before providing additional support on Phase II. During this phase, resources often limit to US\$150,000 for six months.

On Phase II, the goal is to continue R\&D efforts initiated on Phase I. Funding is based on results obtained during the first phase, on scientific and technical merit, and on commercial potential of the project proposed on Phase II. Sole those who were covered on Phase I are eligible for some resource at this stage. Ordinarily, resources are greater than US\$ 1 million for a two-year period.

On Phase III, it is expected that small companies achieve the commercialization goals resulting from activities on previous Phases. The SBIR program does not finance this phase. Some federal agencies utilize Phase III funded the projects with agreements for production of products, processes or services demanded by the US government and grant.

During the SBIR implementation process, there is institutional autonomy so that the agencies can choose their rows in public calls. This is a feature of the American model, decentralization of actions. Furthermore, it is a competition procedure amongst companies during selection on Phases I and II that allows compa- 
nies to obtain government support. The program's non-reimbursable resources pay $100 \%$ of the costs and allow a certain profit for the companies, which is a peculiar characteristic of this tool (CONNELL, 2014).

Between 2000 and 2015, the program financed over US\$ 26 billion $^{8}$ with grant on small companies R\&D projects (GORDON, 2017). In the recent years, over US\$ 2 billion have been invested, annually.

As previously highlighted, many times, such companies end up signing sales agreements with the US government or some agencies prefer to use subsidies to stimulate projects that reach Phase III. Therefore, a cycle is closed in which companies that have reached a relative success have got the chance to sell technologies for the public sector, especially in the military. Many of the government institutions that command the SBIR process connect projects to their internal needs (CONNELL, 2014; ELDER et al., 2013). Often, such technologies are at the frontier of knowledge and constitute development needs relevant to the public institutions. . SBIR may, in a way, be considered a public procurement policy in the pre-competitive phase of the innovative process (ELDER et al., 2013). This is due the fact that the program is implemented ultimately on initial stages of the innovation process, when there is greater risk. In the case of defense, it is ordinary to use purchase contracts (CONNELL, 2014). The DOD is the one that better applies this program's resources, in few cases reaching close to $55 \%$ of total, followed by the Department of Health and Human Services (HHS) and Department of Energy (DOE) (GORDON, 2017).

Many agencies have been seeking ways to finance SBIR's Phase III of the process, given the potential that the program has presented and the difficulty that companies find when entering the market. The most radical experience commenced with the Central Intelligence Agency (CIA), in 1999, when it was given green light to fund its own venture capital firm called In-Q-Tel. The US Army created its own organization, called OnPoint, in 2003, and Nasa created, in 2006, the Red Planet Capital, amongst others (BLOCK, 2008). Above and beyond, many venture capital investors bet on companies that make to Phase III. These investors will not invest on these companies until the whole selection and funding processes have already been performed by the government (CONNELL, 2014).

One of the advantages that the SBIR model has presented to agencies with available resources to apply, is that the program allows to recognize a series of ondevelopment technologies and apply to their internal needs. Researchers and employees of these institutions cannot assay the entire process of knowledge. Also, the model encourages the development of technologies that the internal team does not master or does not have available time to develop, which provides a great capillar-

\footnotetext{
8 "In US, government programs such as the Small Business Innovation Research (SBIR) and the Advanced Technology Program (ATP) within the US department of Commerce have provided 20-25 percent of total funding for early stage technology firms" (MAZZUCATO, 2013, p. 1264).
} 
ity of new knowledge (BLOCK, 2008). These technologies may, posteriorly, be used civilly and generate more strength for the country's industry. ${ }^{9}$

In short, SBIR has been responsible for fostering the interaction of a series of differentiated tools: public procurement, technological orders, and grant. Thus, it is a model capable of fostering and inducing generation and diffusion of knew knowledge.

\section{GERMANY: THE INDUSTRY-FRIENDLY MODEL}

The German productive sector, within its different sectors, presents an outstanding feature in its innovation process that differs from the American model previously presented: US's model is based on innovations considered more "radical" or more disruptive to the ongoing technological paradigm, largely generating new companies, and strengthening the larger ones. The German model, in its turn, is based on innovations considered "incremental", of high technological quality and on specific industrial niches (Wessner, 2013). This does not mean that the countries companies use less technological content, or that do not work on the cutting edge of knowledge, yet the corporations in the region seek competitiveness in the sectors where they operate, and within current paradigms. Therefore, Germany is characterized by innovating on well-established industries in ways of keeping its worldwide leading position in sectors such as automotive, chemical, mechanical, electronic, materials, and, more recently, renewable energies. Often these companies, which are in their majority are typically family-owned, work in niches with great international competitiveness, using long-term strategies, and they are, in many cases, small and medium-sized enterprises - the so-called Mittelstand ${ }^{10}$ (Parilla et al., 2015). These companies may be characterized as Made in Germany (MeyerStameR, 2000). Thus, the German model focuses on companies' demands for technological development and these are peculiar for being exporters with international leadership in their segments.

In the German innovation system, STI origin, primarily, from the federal government, but in few cases the 16 states participate (lander), as it will be understood in the Fraunhofer model. The institutions responsible for policy development and implementation of innovation programs rely on some key players, such as the Ministry of Education and Research (BMBF) and the Ministry of Economy and

\footnotetext{
9 "Companies like Apple, Compaq, Intel and many others received early stage financing government funding programmers like SBIR” (Mazzucato, 2013, p. 338).

${ }^{10}$ This group of companies - Mittelstand - represents, according to BMWi's data (BMWi, 2013) around $99 \%$ of the total of companies in the country, and they contribute with $56 \%$ of the German economic production and they employ more than 15 million workers. From 2000 to 2010, exports raised to almost $30 \%$ and represent almost $20 \%$ of all German exports. From 2008 to 2010, it was ascertained that $54 \%$ of this companies put some innovative product or process in the market (BMWi, 2013). These data evidence the relevance of this set of companies to the German economy.
} 
Energy (BMWi). Under the scope of the federal innovation policy subsystem, there are two main modalities of support for research and development, according to Edler and Kuhlmann (2008): firstly, direct support of financing to innovation projects of companies using non-reimbursable resources for the interaction between companies and academia/research labs and grant, which fundamentally occurs from individual applications in specific foment programs, e.g., the Industrial Research Association $(\mathrm{AiF})$ case. Secondly, the financial resources modality called basic funding for institutions, e.g., the Fraunhofer case (Gordon, 2017). This last modality means a budget so that the institution has minimum resources to create internal capacity of C, T \& I, according to its performance in the value chain. Great amount is intended for "industry-friendly", according to Edler and Kuhlmann (2008).

To better understand the role of the Sate in the German NIS, the AiF case, an institution which operates financing for innovation projects, will be assayed. Next, the Fraunhofer case, which operates in the basic funding model.

\section{Industrial Research Association (AiF)}

Considering the institutions that strengthen the innovative capacity of the German industry, AiF stands out, a non-profit association which operates the country's innovation policies, allocating the non-reimbursable resources of federal government into $R \& D$ projects.

The institution gathers over 100 industry associations representing more than 50 thousand small and medium-sized enterprises (SME) and over 1,200 affiliated research institutes (AiF, 2015) and administers public funding programs whose mission is to foment competitiveness of the German SME, amongst which are the Mittlestand. Addressed to this issue is a model that seeks to strengthen the interaction between the private and the public sectors in ways to foster industry development.

According to the institution's data, in 2013 and 2014, the State contributed to the AiF, on average, $€ 500$ million a year of non-reimbursable resources to strengthen innovative capacity of companies (AiF, 2015).

AiF's cornerstones are the following:

- Collective research to benefit all sectors of industry;

- Government R\&D programs to raise companies' individual innovation capacity: ZIM (Zentrales Innovations Programm Mittelstand), focused on R\&D cooperation among SME and between SME and research institutes;

- International activities to strengthen SME's capacity to succeed in increasingly internationalizing markets.

The collective research projects between companies and research institutions seek to stimulate the sharing of R\&D activities amongst companies. This model occurs in the pre-competitive phase of the innovative process (AiF, 2015). Thus, with non-reimbursable resources, interaction between companies and STI is encouraged to generate complementarity in the process of generation and diffusion of new 
knowledge. Resources are headed to solve industry problems and contribute to enhancement of businesses competitiveness.

In 2013, for instance, 1,500 projects worth almost $€ 140$ million (the program's resources come from BMWi) were funded in this model, wrapping over 15 thousand companies and 690 research institutions (AiF, 2015). Note that there is a wide range of companies profited by the projects.

Another AiF tool fostered by The Central Innovation Programme for SMEs - ZIM, a BMWi's program. This program seeks to rouse, using non-reimbursable resources, SME's R\&D projects without, however, a sectorial focus. The goal is to strengthen local companies' competitive capacity. The program may have resources for cooperative projects among companies and between companies and STI. In 2013, over 3,000 R\&D projects and over $€ 350$ million were applied by the government to stimulate innovative projects which strengthen the SME's innovative capacity.

The program adopts the following support lines:

- Individual projects: financing of R\&D projects of SME;

- Cooperation projects: financing R\&D cooperation projects among SME, or between SME and STI;

- Cooperation networks: financing the management of innovative companies' networks and R\&D projects generated by them (minimum requirement: six German SME partners).

Table 2: Maximum Foment Rates (grant and non-reimbursable resources for STI and enterprise interaction) for Individual Projects, and Cooperation Projects

\begin{tabular}{|c|c|c|c|}
\hline $\begin{array}{c}\text { Company } \\
\text { size }\end{array}$ & $\begin{array}{c}\text { Individual } \\
\text { projects }\end{array}$ & $\begin{array}{c}\text { Cooperative } \\
\text { projects }\end{array}$ & $\begin{array}{c}\text { Cooperative projects with } \\
\text { international partners }\end{array}$ \\
\hline $\begin{array}{c}\text { Small East German } \\
\text { Companies }\end{array}$ & $45 \%$ & $50 \%$ & $55 \%$ \\
\hline $\begin{array}{c}\text { Small West German } \\
\text { Companies }\end{array}$ & $40 \%$ & $45 \%$ & $50 \%$ \\
\hline Mid-size Companies & $35 \%$ & $40 \%$ & $40 \%$ \\
\hline $\begin{array}{c}\text { Other Mid-size } \\
\text { Companies }\end{array}$ & $25 \%$ & $30 \%$ & $50 \%$ \\
\hline Research institutions & \multicolumn{3}{c}{ May claim up to $100 \%$ of the costs } \\
\hline
\end{tabular}

Source: ZIM, 2015. 
The limits of the amounts per project are:

- For the companies, the eligible costs per project (or sub-project, in the case of cooperation projects) are limited to $€ 380,000$;

- For research institutes, the eligible costs per sub-project are limited to $€ 190,000$.

The model has great potential for leveraging investments in innovation, since it finances the costs of projects with non-reimbursable resources (reducing risk for companies), which can be interesting for companies, for they may finance up to $55 \%$ of total amount of the projects in a few cases. Resources in this framework push the State to contribute with part of the investment, but the company must leverage the remainder of the project's amount.

There is a priority, perhaps not mission oriented, of technologies and sectors, though targeted at a group of companies (SME) and to stimulate interaction among agents. The focus is on the demands of companies and a group of companies that have as one of their characteristics to be exporters. The institution has had more importance to the niche of enterprises it fosters, since it strengthens the generation of knowledge networks among different agents.

\section{The Fraunhofer Society model}

The German system was structured to create a sophisticated and complex framework of institutions that may assist in the scientific, technological and innovative development of the country. Nonetheless, there is a split of function in the innovation value chain among some of the main players in the German innovation system. These are institutions that have as one of their premises the use of financial resources in the modality of basic funding, though they are not limited to it in some cases.

Table 3: Key Research Institutions in Germany

\begin{tabular}{|c|c|}
\hline Institution & Focus \\
\hline Max Planck Society & Basic Research \\
\hline Helmholtz Association & Basic Research ("Big Science") \\
\hline Fraunhofer Society & Applied Research \\
\hline Leibnitz Association & Miscellaneous \\
\hline
\end{tabular}

Source: Wessner, 2013, p. 237.

In this division of the country's value chain, the institution with the role to stimulate the interaction between innovation centers and companies is the Fraunhofer Society, whose intermediary role is to link research with industries' needs in ways to strengthen German's industry competitiveness.

Fraunhofer seeks to meet the demands of the private companies and public 
sector, aiming to enhance local and industrial competitiveness in the country. One of its roles is to support oriented applied research considering the results that can generate innovation and new solutions for the companies, benefiting either the private or the public sector which have hired it (Wessner, 2013; Mason; Wagner, 2006).

Fraunhofer is internationally renowned as one of the main institutions that develop projects with industry (Wessner, 2013; Mason; Wagner, 2006). The institutes have been built in ways to support the private sector through new knowledge and technology transfer (Mason; WagnER, 2006). Up to date there are 72 centers spread across Germany. Also, there is a regional component to de-centralize the operation and articulation with regional development of the productive structure. Each one of these centers has high complexity infrastructure in modern buildings and highly trained personnel. These institutes specialize in some technology or sector and keep great proximity to the regional industry.

An interesting fact is that institutes may allocate players capable of working together starting from the qualification of highly qualified personnel up to the activity of innovation for companies. Besides the proximity to universities, the regional component allows many companies to access the institution's competences. This suggests a systemic view of the innovative process not limited to a disperse set of actions, but to an institutionality capable of organizing actions aimed at industrial development, coordinated with the country's policy, and within the logic of a highly competitive industry with the training of highly qualified personnel (Wessner, 2013).

Because the model stated is lined up largely with the solution of problems driven by the industry's needs, it is said that the institution works, largely, in German's traditional industry sectors, for instance, automotive, chemical and mechanical (Wessner, 2013). Thus, generates a capacity to absorb knowledge as of interaction between the Fraunhofer and the companies. SMEs, which often face difficulties to sustain their own R\&D laboratories and even retain qualified personnel, may access the different laboratories of the institution to contribute to their innovation strategies. The projects developed are, mostly, of short term and have an incremental feature, though keep companies in constant competitivity capacity. This relates to government priorities, which seek to foster institutions with actions focused on the applicability of what is being developed (Wessner, 2013). The State's support model, from basic funding for Fraunhofer, is presented in Figure 4.

In general, as shown in Figure 4, the model works as the follows: from the total budget offered, each Fraunhofer Institute get a fixed amount of $€ 600,000$ (basic 1) plus $12 \%$ of the total amount that relies on the size of the institute supported (basic 2). Units that collect between $25 \%$ and $55 \%$ of its resources from companies get a complementary $40 \%$ of the amount raised with companies in their budget (basic 3). The logic of the institution is based on the following premise: institutions that are below $25 \%$ do not suitably meet the companies in their demands for projects of innovation. On the other hand, those operating above $55 \%$ are, probably, developing projects with companies of lower technological content 


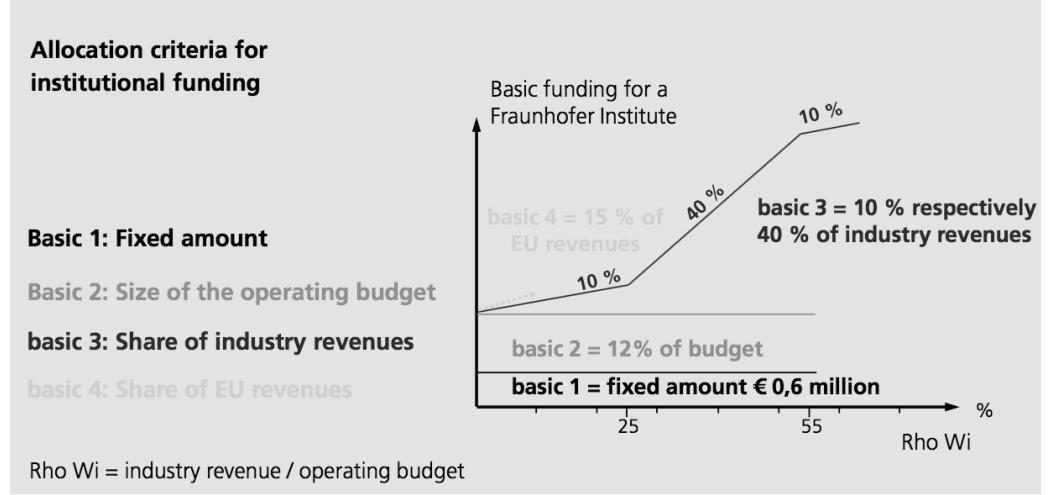

Source: Fraunhofer 2016.

and, possibly, doing lots of routine technological service. In addition, the institutions above this range do not allow their technical staff to focus on generating knowledge that may, in the future, contribute to partnerships with companies.

The main funding sources are the following three:

- Federal and state government resources provide institutes with means to develop research which may, in the future, constitute the basis of knowledge transfer oriented to the business sector - basic funding;

- Resources from research project commissioned by public partners to support long-term development of state-of-the-art technological innovation which will address industrial needs;

- Resources from research contracts with the industry allow direct access to Fraunhofer's range of competences.

There is a mix of resources from federal and state government, European Union, and there is another source of resources from the industry. The institution works largely with demands originated from the productive sector and government's long-term demands. The institution's allocated resources from public sources establish relevant support and contribute to reduce costs of companies' projects, since they subsidize great amount of the institution's needs. Table 4 presents the Fraunhofer's revenue and Research Contracts Funding:

Table 4: Fraunhofer revenue and Fraunhofer's Research Contracts Funding (current euro million)

\begin{tabular}{|c|c|c|c|c|c|c|c|c|c|c|}
\hline Years & 2005 & 2006 & 2007 & 2008 & 2009 & 2010 & 2011 & 2012 & 2013 & 2014 \\
\hline Fraunhofer Revenue & 1,253 & 1,186 & 1,320 & 1,401 & 1,617 & 1,657 & 1,849 & 1,926 & 2,010 & 2,060 \\
\hline $\begin{array}{c}\text { Research Contracts } \\
\text { Funding }\end{array}$ & 1,068 & 1,032 & 1,164 & 1,291 & 1,340 & 1,402 & 1,515 & 1,614 & 1,661 & 1,716 \\
\hline
\end{tabular}

Source: Self elaboration from Fraunhofer's yearbook data. 
Note that Fraunhofer's resources reached up to $€ 2$ billion in 2014, with research and development projects essentially. According to Figure 5, investments on research remained above $80 \%$ of the institution's revenue, and it can be added to this figure expenses with research for the sector of defense, ${ }^{11}$ which, in the year 2014 , reached $5.7 \%$. It is also noted that expenses with infrastructure are not priority and are well below the others. Focus has been on research with companies or with the public sector.

Figure 5: Revenue Allocation Percentage

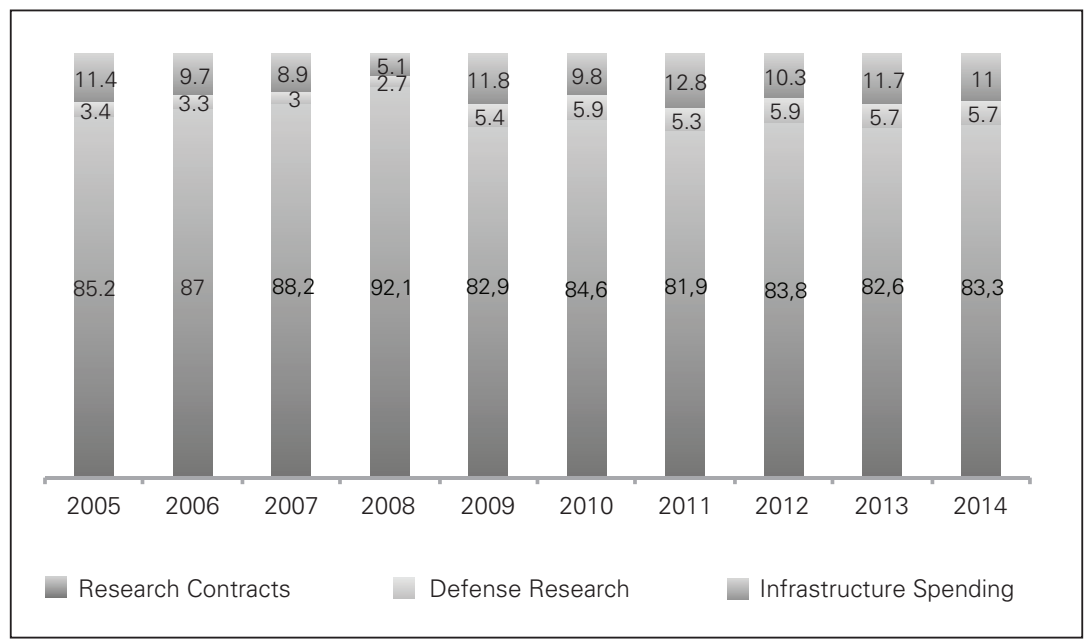

Source: Self elaboration from Fraunhofer's data.

Figure 6 shows the source of the institution's financial research income. Note that there is a great percentage of resources originated from the public sector.

Figure 6 shows that the industry's percentage in projects dropped from $40 \%$, in 2005 , to $36 \%$, in 2014 (companies often utilize resources from subsidies or other means of financial support of the State, as of the case of AiF - Wessner, 2013). It is also noted that the public sector participates with over $60 \%$ of the resources destined for the research projects in the institution (base funding plus revenue with public sector's projects). In this context, it is an institution that develops $R \& D$ activities to strengthen the business sector in a model of public-private interaction, in which the government injects great amount of resources, capable of contributing

\footnotetext{
${ }^{11}$ The importance of the State to the beginning of Fraunhofer organization can be distinguished by projects with the defense sector at the beginning of the constitution of the institution: "For many years afterward, 'military funding accounted for more than half of the Fraunhofer-Gesellschaft's total research budget" (Wessner, 2013, p. 278). However, in the 1970s this situation changes: “In 1973, Fraunhofer received the status of a federal research organization and began receiving funding from the BMFT, now the BMBF. Beginning in the early 1970s the Fraunhfer made a phased shift in emphasis away from military R\&D toward civilian applications” (Wessner, 2013, p. 279).
} 
Figure 6: Percentage of Financing for Research Contracts (\%)

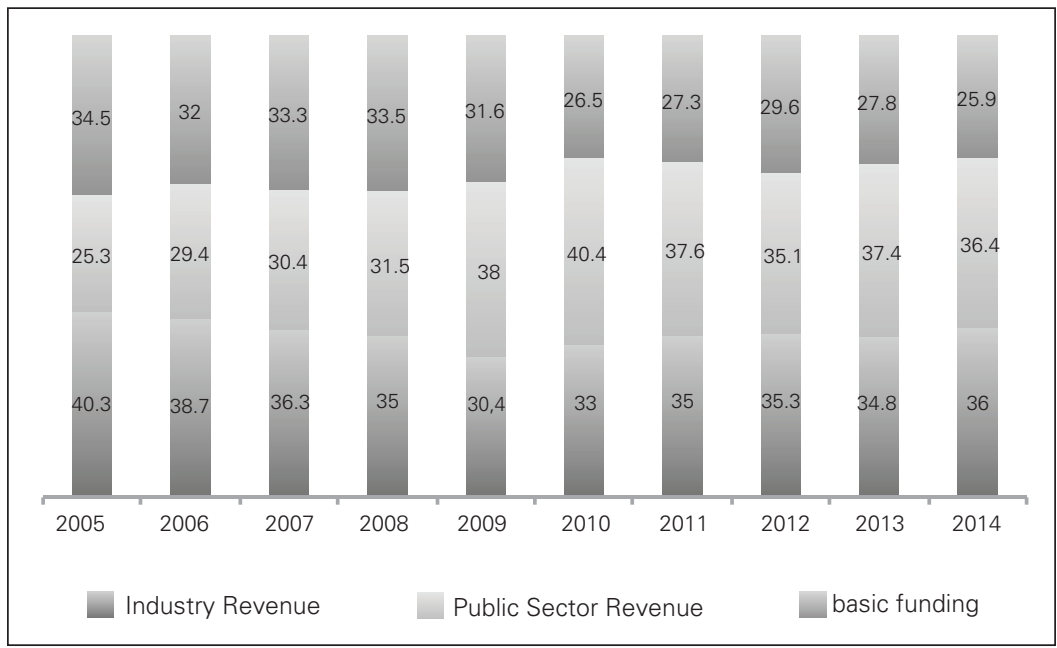

Source: Self elaboration from Fraunhofer's data.

to the innovative capacity of the companies in the country. It should be noted that, as of 2009 on, the year of the international financial crisis, the percentage of research of the public sector reached $38 \%$, reversing the scenario in which the industry was the largest applicant for projects. This framework was extended until 2014; nonetheless, there was a reversal of the private sector, which resumed growth in the institution's revenue. Therefore, to a large extent, when considering the Fraunhofer's model, the role of public resources and the role of the State are crucial for the implementation of the institution's model (Wessner, 2013; Connell, 2014).

Basic funding from governmental resources lowers revenue requirements from other sources and allows for more solid revenue to maintain personnel, infrastructure, and other expenses. This is a way to keep prices lower for the projects of the business sector. On the other hand, it is not enough to pay for all the institution's costs, which needs to seek projects with companies and the public sector. Thus, the interaction between public and private is encouraged to maintain an institution with high technical competence to comply with the demands of the business sector, but at the same time makes clear that its role is to work to meet the needs of the productive sector. The German model encourages interactions among research institutions, such as Fraunhofer and industry, as a key-variable for the innovation process.

\section{CONCLUSION}

One of the main results presented on the comparative analysis of Germany and the USA is that, although specific to each national context (in terms of assorted institutional, productive, scientific and technological characteristics), public innovation policies are undoubtfully active, explicit and strategically oriented. The char- 
acteristics of the role of the State are matched for both USA and Germany. First, an active State capable to induce the innovative process in NIS. Second, focus on fostering companies as the locus of innovation activity. Third, use of risk reduction tools and dubiety as a priority. Fourth, use of a mix of instruments on the supplyside (e.g., non-reimbursable resources for STI and enterprise interaction and grant) and on the demand side (e.g., public procurement and private sector demands). Fifth, actions that seek to strengthen the cooperation process amid the different agents of the economy, be it amid public demands and the private sector, amid companies, amid STI and companies.

Therefore, despite local specificities, it is highlighted that to create innovation policy to generate and strengthen a productive sector with a greater capacity for generation and broadcast of new knowledge, it is imperative that the State is active and non-passive. The use of instruments for risk and uncertainty reduction is a primordial feature. Also, it is crucial that the public sector pursues to list the demands of different existing technologies (public and private) to guide the use of the different policy tools. Thus, the State can stimulate generation and diffusion of new knowledge.

\section{REFERENCES}

AiF (2015). Research for SMEs - AiF at a Glance, 2015. Available at: <https://www.aif.de/fileadmin/ user_upload/aif/service/mediathek_PDF/aif-info-flyer-engl.pdf>. Accessed August 28, 2018.

Atkinson, R. D.; Ezell, S. J. (2012) Innovation economics: the race for global advantage. New Haven, Connecticut, EUA: Yale University Press.

Block, F. (2008) "Swimming against the current: the rise of a hidden developmental state in the United States", Politics \& Society, 36 (2): 169-206.

Bresser-Pereira, L. C. (2017) "The two forms of capitalism: developmentalism and economic liberalism”, Revista de Economia Política, 37 (4): 680-703.

Cassiolato, J. E.; Lastres, H. M. M. (2005) “Sistemas de inovação e desenvolvimento: as implicações de política”, Revista São Paulo em Perspectiva, 19 (1): 34-45.

Colecchia, A. (2006) What indicators for science, technology and innovation policies in the $21^{\text {st }}$ century. Blue Sky II Forum - Background. Paris: OCDE.

Connell, D. (2014) Creating markets for things that don't exist - The truth about UK government R\&D and how the success of SBRI points the way to a new innovation policy to help bridge the valley of death and rebalance the UK economy. Cambridge: Centre for Business Research.

Edler, J.; Cunningham, P.; Gök, A.; Shapira, P. (2013) "Impacts of innovation policy: synthesis and conclusions", NESTA Working Paper, 13/21.

Edler, J; Kuhlmann, S. (2008) "Coordination within fragmentation: governance in knowledge policy in the German federal system”, Science and Public Policy, 35 (4): 265-276.

Gadelha, C. A. G. (2001) "Política industrial: uma visão neo-schumpeteriana sistêmica e estrutural”, Revista de Economia Política, 21 (4): 149-71.

Gadelha, C. A. G. (2016) "Política industrial, desenvolvimento e os grandes desafios nacionais", O futuro do desenvolvimento: ensaios em homenagem a Luciano Coutinho. Campinas: Editora Unicamp, p. 215-251.

Gordon, J. L. P. L. (2017) Papel do estado na política de inovação brasileira 2007-2015: uma análise do uso dos principais instrumentos. Tese de doutorado. Instituto de Economia da Universidade Federal do Rio de Janeiro. 
Lundvall, B-Å. (2007) "Innovation system research: where it came from and where it might go", Globelics Working Paper, 2007-01. Saratov, Global Network for Economics of Learning, Innovation, and Competence Building System, 2007.

Mazzucato, M. (2013) The entrepreneurial state: debunking public vs. private myths in risk and innovation. London: Anthem Press.

Meyer-Stamer, J.; Waltring, F. (2000) Behind the Myth of the Mittelstand Economy. The Institutional Environment Supporting Small and Medium-Sized Enterprises in Germany. Institute for Development and Peace at the Gerhard-Mercator-University Duisburg, Report 46, 2000.

Mowery, D. C. (2010) “Military and innovation", Handbook of the Economics Innovation, 2, Cap 29, 1221-1256.

Mowery, D. C. (1992) “The U.S. national innovation system: origins and prospects for change”, Research Policy, 21 (2): 125-144.

Parilla, J.; Leal, J.; Trukillo, L. J.; Berube, A. (2015) Skills and Innovation Strategies to Strengthen U.S. Manufacturing - Lessons from Germany. The Brookings Institution.

Rauen, A. T. (2017) "Risco e incerteza na aquisição pública de P\&D: a experiência norte-americana", Políticas de inovação pelo lado da demanda no Brasil. Brasília: IPEA, p. 375-412.

Reinert, E. S. (1999) "The role of the state in economic growth”, Journal of Economic Studies, 26 (4/5): 268-326.

Rothwell, R. (1983) "The difficulties of national innovation policies", The trouble with technology. Macdonald, S.; Lamberton, D. McL; Mandeville, Th. (eds). London, Frances Pinter.

Robinson, K. D. C. (2008) "U.S. Federal Government Procurement: organizational structure, process, and current issues", International Handbook of Public Procurement. Abingdon Oxfordshire, United Kingdom: Taylor \& Francis Group, LLC.

Squeff, F. de H. S.; De Negri, F. (2017) "Ciência e tecnologia de impacto: uma análise do caso do DARPA”, Políticas de inovação pelo lado da demanda no Brasil. Org. André T. Rauen. Brasília: IPEA, 413-442.

Vonortas, N. S; Bhatia, P; Mayer, D. P. (2010) Public procurement and innovation in the United States. Washington, DC, EUA: Center for International Science and Technology Policy \& Department of Economics. The George Washington University.

Wessner, C. W. (2013) Committee on 21st Century Manufacturing: the role of the manufacturing extension. Washington, DC, EUA: National Research Council.

ZIM (2015) Central Innovation Programme for SMEs. Federal Ministry for Economic Affairs and Energy. Berlim, Alemanha. Available at: <http://www.zim-bmwi.de/download/infomaterial/zim-brochure-em>. Accessed August 28, 2018. 